\title{
STUDIES ON ENHANCING THE EFFICIENCY OF ZLD PLANT FOR TANNERY EFFLUENT BY IMPLEMENTING LOW-COST AMBIENT AIR EVAPORATOR SYSTEM
}

\author{
R. Rajkumar ${ }^{1}$, S. Sathish ${ }^{2, *}$ and P. Senthilkumar ${ }^{2}$ \\ ${ }^{1}$ Scientist 'C' ,Central Pollution Control Board, Banglore-560010, India. \\ ${ }^{2}$ Department of Chemical Engineering, Sathyabama University, Chennai-600 117. \\ *E-mail: sathish.chemical@ sathyabamauniversity.ac.in
}

\begin{abstract}
The waste generated from tanning process poses a threat to the environment and has a major challenge of waste management. In India, all tannery industries are bound to achieve Zero Liquid Discharge (ZLD) with the objectives of recovery of water and prevention of environment. This study deals with the mechanical evaporation to increase the efficiency of concentrating the tannery effluent. The evaporator works on the principle of using ambient air instead of hot air for the process of evaporation. The project was undertaken to understand the process flow and design of the evaporator setup and to optimize the process parameters to increase the outlet concentration of the effluent to $85000 \mathrm{mg} / \mathrm{L}$ for the single run, so that the area required for sludge drying was reduced.The outlet concentration was varying from $42000 \mathrm{mg} / \mathrm{l}$ to $43306 \mathrm{mg} / \mathrm{l}$ with a mass of dry air as $38570 \mathrm{~kg} / \mathrm{h}$. The preheating of air improves the concentration of outlet to $55690 \mathrm{mg} / \mathrm{l}$.
\end{abstract}

Keywords: Tannery effluent, ZLD, Ambient air evaporator, Waste management.

(C) RASĀYAN. All rights reserved

\section{INTRODUCTION}

The tanning industry is one of the industries that considered as high polluting industry. ${ }^{1}$ Tanning generates a large volume of waste water. ${ }^{2}$ On the average of $28-30 \mathrm{~m}^{3} / \mathrm{h}$ of effluent is generated for 1000 $\mathrm{kg}$ of raw material. ${ }^{3,4}$ Tannery industry generates wastewater with the variable $\mathrm{pH}$ and high concentration of BOD, COD, suspended solids and heavy metals. ${ }^{5}$ It was found that $20 \%$ of chemicals absorbed by the leather, and the rest is washed away with the process water. ${ }^{6,7}$ The sludge settled during the physicochemical treatment as well as the wasted sludge from the oxidation ditches was taken to the sludge well and pumped to sludge drying beds. ${ }^{8}$ The dewatered sludge was disposed of (Hafez et al., 2002). According to norms prescribed by TNPCB $222 \mathrm{~m}^{2}$ of solar pan, area is required to evaporate $1 \mathrm{~m}^{3}$ of saline effluent per day. ${ }^{9}$ The main aim of this work is to increase the concentration of sludge leaving the evaporator and reduce the consumption of energy and area for the solar pond. The major issues faced in the multi-effect evaporator by the tannery effluent treatment plants were consuming high energy for desalination, corrosion, and scaling of the evaporators resulting in frequent interruptions and downtime that affects processing capacity. ${ }^{10,11}$ Compared to normal evaporators the ambient air evaporators require less area, low capital investment, low energy consumption, can handle high TDS content and no additional crystallizer is required to achieve ZLD. In this work, studies were carried out for the evaporation rate at various effluent flow rates and changes brought forth like passing a preheated air that can ease the evaporation rate so that the area required by solar evaporation was reduced and no need for the alternate effluent treatment process.

\section{Process of Evaporation}

\section{EXPERIMENTAL}

The effluent (RO reject) was collected in a sump and it is pumped to the evaporator through an atomizer operating at a speed of about $11000 \mathrm{rpm}$. The effluent is fractured mechanically into a very fine mist, of 4 to 5 micron in a chamber. A large volume of ambient air is passed through an evaporator in which the saline effluent is dispersed to a fine mist by the atomizer. The air and mist are mixed within the chamber 
RASĀYAN J. Chem.

Vol. 11 | No. 1 |13-17 | January - March | 2018

and the effluent gets evaporated. The evaporation is primarily based on ambient air temperature and humidity. The moist air leaves from the top of the chamber after demister made of polypropylene baffles, traps the salt carried by air and only the moist air is sent outside the tower. The concentrated effluent falls at the bottom and it is recirculated until it reaches desirable concentration. The temperature inside the chamber becomes less than ambient temperature because of evaporation. The slightly higher temperature of the ambient air aids the evaporation. The cycle is repeated until the salt concentration reaches about 1 , $00,000 \mathrm{mg} / \mathrm{l}$. Then the effluent is drawn from the bottom of the settling tank and sent to solar tunnel driers for solidification (Fig.-1).

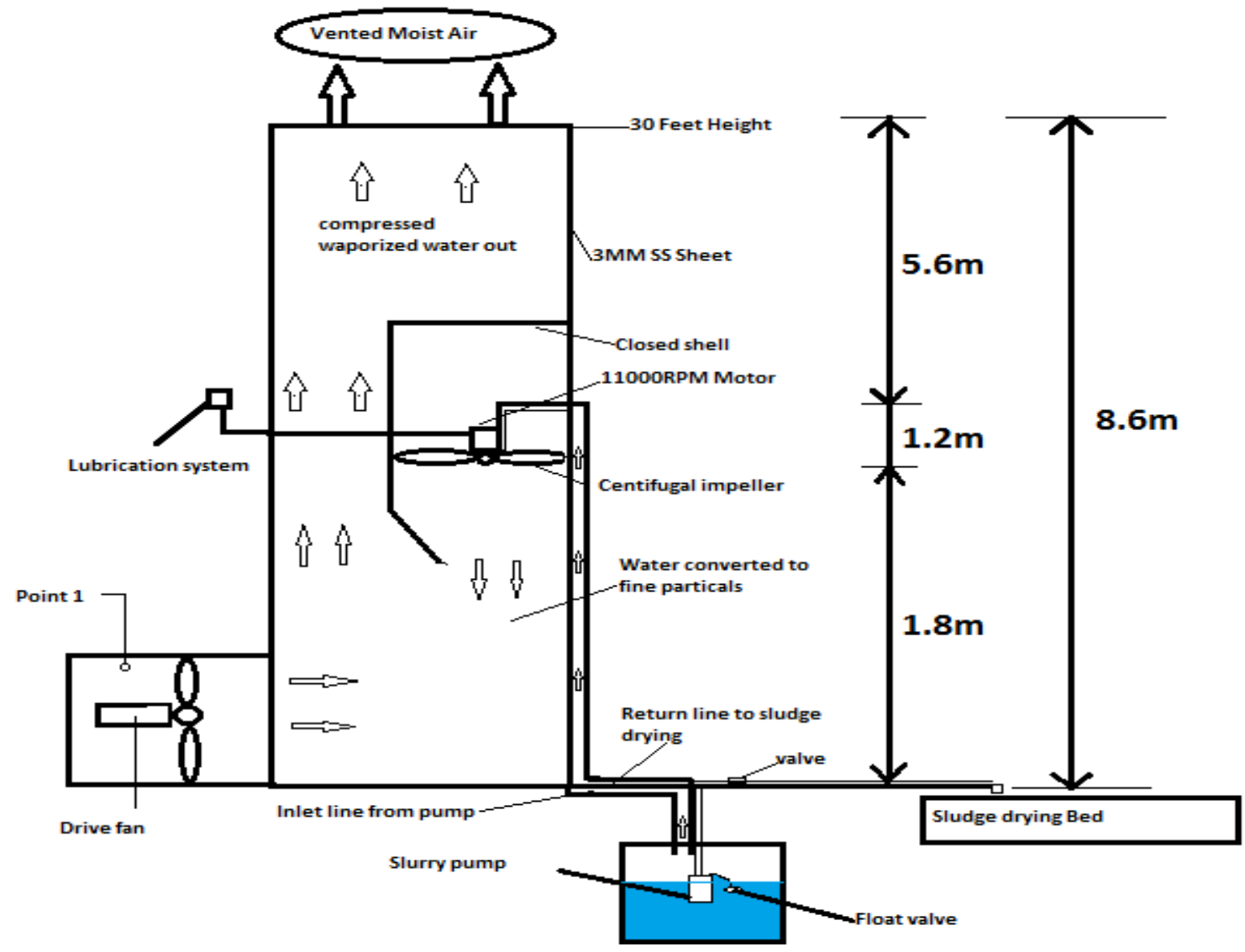

\section{Preheating the Air}

Fig.-1: Schematic representation of Ambient Air evaporation system

In order to raise the temperature of the incoming air, a preheater is used. Tubular pre-heater was used for preheating the air from the exhaust gas. ${ }^{12,13}$ Ambient air is forced by a fan through ducting, with one end collecting air for the preheater and at other end gives the heated air by passing through the preheater tubes towards the atomizer. Steam from the tannery boiler unit was also used for preheating the air. This hot air comes into contact with an atomizer. A partition is placed inside the evaporation unit. This increases the directional flow of the incoming air towards the atomizer. Since the air coming in will be directed towards the atomizer, it will provide higher contact area, thus providing a good chance of an increase in outlet concentrations.

\section{Open Pond Evaporation}

The high TDS stream from the tannery and the outlet concentration stream from the ambient air evaporator is sent to open ponds of evaporation ${ }^{14}$. The concentration of the solutions increases with depth. ${ }^{15}$ High concentration effluent at the bottom does not mix with the low concentration effluent above 
RASĀYAN J. Chem.

Vol. 11 | No. 1 |13-17 | January - March | 2018

it, so when the bottom layer of water is heated, convection occurs separately in the bottom and top layers. This reduces heat loss to the great extent and allows for the high concentration effluent to get up to $90^{\circ} \mathrm{C}$ while maintaining $30^{\circ} \mathrm{C}$ low concentration. This hot, salty water can then be pumped away for use in electricity generation.

\section{RESULTS AND DISCUSSIONS}

The evaporator is able to evaporate about 15,000 liters per day from the initial reject volume of 20,000 liters. The TDS is increased from about 60,000 to $175,000 \mathrm{mg} / \mathrm{l}$. Average evaporation achieved was $75 \%$. The concentration of wastewater increases from $7 \%$ to $13 \%$ in one hour for the various flow rate (Table2).

Table-1: Specification of the Evaporator

\begin{tabular}{c|c}
\hline Parameters & Values \\
\hline Duct Area & $2.7 \times 1.8 \mathrm{~m}^{2}$ \\
\hline Height of Tower & $8.6 \mathrm{~m}$ \\
\hline Height between the bottom of Atomizer and Forced Draft Fan & $1.8 \mathrm{~m}$ \\
\hline Height between Top of tower to top of Atomizer & $5.6 \mathrm{~m}$ \\
\hline Capacity & $20 \mathrm{~m}^{3} /$ day \\
\hline
\end{tabular}

For $1000 \mathrm{LPH}$ of wastewater flow the runs were carried out to determine the efficiency of the evaporator by increase the temperature of the air. The result shows that the percentage of concentration increases up to $35 \%$ in one hour and an average amount of water evaporated was $56 \mathrm{~kg} / \mathrm{hr}$ (Table-3).

Table-2: Variation in the Concentration of Wastewater at Evaporator Outlet at various Flow Rates

\begin{tabular}{c|c|c|c}
\hline Parameters & $600 \mathrm{LPH}$ & $800 \mathrm{LPH}$ & $1000 \mathrm{LPH}$ \\
\hline DBT $\left({ }^{\circ} \mathrm{C}\right)$ at inlet & 26 & 26 & 26 \\
\hline WBT $\left({ }^{\circ} \mathrm{C}\right)$ at inlet & 24.5 & 24 & 23 \\
\hline DBT $\left({ }^{\circ} \mathrm{C}\right)$ at outlet & 24 & 24 & 23 \\
\hline WBT $\left({ }^{\circ} \mathrm{C}\right)$ at outlet & 23.5 & 23.5 & 22.5 \\
\hline Conductivity at the Inlet $(\mu \mathrm{S} / \mathrm{Cm})$ & 54.7 & 55.7 & 56.9 \\
\hline Conductivity at the outlet $(\mu \mathrm{S} / \mathrm{Cm})$ & 58.7 & 60.5 & 64.5 \\
\hline Concentration of the solids at the Inlet $(\mathrm{mg} / \mathrm{l})$ & 38290 & 38990 & 39830 \\
\hline Concentration of the solids at the Outlet $(\mathrm{mg} / \mathrm{l})$ & 41090 & 42350 & 45150 \\
\hline Total amount of sludge Inlet $(\mathrm{kg} / \mathrm{h})$ & 660 & 776 & 1018 \\
\hline Solids present in the sludge at Inlet $(\mathrm{kg} / \mathrm{h})$ & 38.29 & 31.2 & 39.41 \\
\hline Amount of Water present at the Inlet $(\mathrm{kg} / \mathrm{h})$ & 621.71 & 744.7 & 978.59 \\
\hline Total amount of sludge at the Outlet $(\mathrm{kg} / \mathrm{h})$ & 640 & 760 & 983 \\
\hline Solids present in the sludge at the Outlet $(\mathrm{kg} / \mathrm{h})$ & 41.09 & 42.35 & 45.15 \\
\hline Amount of Water present at the Outlet $(\mathrm{kg} / \mathrm{h})$ & 598.91 & 717.65 & 937.85 \\
\hline Water evaporated $(\mathrm{kg} / \mathrm{h})$ & 22.98 & 27.05 & 40.74 \\
\hline
\end{tabular}

Table-3: Variation in Concentration for $1000 \mathrm{LPH}$ with preheating air

\begin{tabular}{c|c|c|c|c|c|c|c}
\hline Parameters & Run 1 & Run 2 & Run 3 & Run 4 & Run 5 & Run 6 & Run 7 \\
\hline DBT $\left({ }^{\circ} \mathrm{C}\right)$ at inlet & 34.2 & 36 & 37.5 & 37.2 & 38.3 & 38.7 & 37 \\
\hline WBT $\left({ }^{\circ} \mathrm{C}\right)$ at inlet & 24.5 & 23.9 & 26.8 & 24 & 24.9 & 23.3 & 23.1 \\
\hline DBT $\left({ }^{\circ} \mathrm{C}\right)$ at outlet & 28.9 & 30 & 30.1 & 27.8 & 29.3 & 28.7 & 28.3 \\
\hline WBT $\left({ }^{\circ} \mathrm{C}\right)$ at outlet & 23.9 & 23.7 & 24.2 & 23.7 & 23.9 & 23.5 & 22.6 \\
\hline $\begin{array}{c}\text { Conductivity of solids } \\
\text { at the Inlet }(\mu \mathrm{S} / \mathrm{Cm})\end{array}$ & 56.9 & 59 & 57.6 & 58 & 59.61 & 57.66 & 57.16 \\
\hline $\begin{array}{c}\text { Conductivity of the } \\
\text { solids at the } \\
\text { outlet }(\mu \mathrm{S} / \mathrm{Cm})\end{array}$ & 77.08 & 77.38 & 74.62 & 76.13 & 77.86 & 75.37 & 79.56 \\
\hline $\begin{array}{c}\text { Concentration of the } \\
\text { solids at the Inlet }(\mathrm{mg} / \mathrm{l})\end{array}$ & 39830 & 41300 & 40360 & 40600 & 41730 & 40360 & 40010 \\
\hline
\end{tabular}


RASĀYAN J. Chem.

Vol. 11 | No. 1 |13-17 | January - March | 2018

\begin{tabular}{c|c|c|c|c|c|c|c}
\hline $\begin{array}{c}\text { Concentration of the } \\
\text { solids at the } \\
\text { Outlet(mg/l) }\end{array}$ & 53960 & 54170 & 52240 & 53290 & 54500 & 52760 & 55690 \\
\hline $\begin{array}{c}\text { Total amount of sludge } \\
\text { at the Inlet }(\mathrm{kg} / \mathrm{h})\end{array}$ & 1002 & 1035 & 1134.4 & 1044.9 & 1042.9 & 1044 & 1018.7 \\
\hline $\begin{array}{c}\text { Solids present in the } \\
\text { sludge at Inlet }(\mathrm{kg} / \mathrm{h})\end{array}$ & 39.83 & 41.3 & 40.36 & 40.60 & 41.73 & 40.36 & 40.01 \\
\hline $\begin{array}{c}\text { Amount of Water at the } \\
\text { Inlet }(\mathrm{kg} / \mathrm{h})\end{array}$ & 960.63 & 993.77 & 1092.0 & 1002.1 & 1001.17 & 1003.6 & 978.65 \\
\hline $\begin{array}{c}\text { Amount of sludge at the } \\
\text { Outlet }(\mathrm{kg} / \mathrm{h})\end{array}$ & 950 & 971.2 & 1101.3 & 1017.2 & 1007.01 & 1011.7 & 953.22 \\
\hline $\begin{array}{c}\text { Solids present at the } \\
\text { Outlet }(\mathrm{kg} / \mathrm{h})\end{array}$ & 53.96 & 54.17 & 52.24 & 53.29 & 54.50 & 52.76 & 55.69 \\
\hline $\begin{array}{c}\text { Amount of Water } \\
\text { present at the Outlet } \\
\text { (kg/h) }\end{array}$ & 896.04 & 917.03 & 1049.0 & 963.93 & 952.51 & 950.99 & 897.53 \\
\hline Water evaporated $(\mathrm{kg} / \mathrm{h})$ & 63.96 & 54.17 & 52.3 & 53.27 & 54.5 & 60.71 & 55.69 \\
\hline
\end{tabular}

\section{CONCLUSION}

Based on this study was carried out to increase the efficiency of the setup and also the concentration variation was compared with modification in preheating the air. The increased air capacity drafters were provided that allowed more mass of dry air to flow inside the setup to increase the solid concentrations. When the pre-heater setup is employed, considerable effects were observed but a restriction in the air flow was witnessed. The higher efficiency or increase of concentration about $53950 \mathrm{mg} / \mathrm{l}$ was achieved. Preheating is required essential during the rainy season, but utilizing the waste heat from the exhaust gas will increase the efficiency of the evaporator. On comparing with conventional multi-effect evaporator system the operating cost and the capital cost was very much reduced.

\section{REFERENCES}

1. Tasneembano Kazi1 and Arjun Virupakshi, International Journal of Innovative Research in Science, Engineering and Technology, 2(8), 4061 (2013).

2. Olivier Lefebvre and Rene Moletta., Water Research, 40(20), 3671 (2006).

3. Saritha Banuraman and T. P. Meikandaan, International Journal of Modern Engineering Research, 3(1), 119(2013).

4. K. Rajalakshmi, Rasayan Journal of Chemistry, 3(2), 305 (2010).

5. Nandy, Tapas Kaul, Shastry, Sunita, Manivel and Deshpande, Journal of Scientific and Industrial Research, 58(7), 475 (1999).

6. A. Belay, Journal of Environmental Protection, 1(1), 53 (2010).

7. H. Fisher and D. Pearce, Salinity reduction in tannery effluents in India and Australia. ACIAR Impact Assessment Series Report No.61, Australian Centre for International Agricultural Research: Canberra. Pp. 33-40 (2009).

8. M. A. Aboulhassan, A. Yaacoubi, and S. Souabi, International Journal of. Environmental Science and Technology, 5(1), 11 (2007).

9. R. Rajamanickam and S.Nagan, Journal of Environmental Research and Development, 5(3), 623 (2010).

10. Sathish Sundararaman, L. Jagadish Kumar and G.Narendrakumar, Research J. Pharm. and Tech., 8(7), 845 (2015).

11. K. K. Sivakumar, C. Balamurugan, D. Ramakrishnan and Leena Hebsi Bhai, Rasayan Journal of Chemistry, 4(2), 264 (2011).

12. M. I. Niyas Ahameda and P.Mohammed Kashif, International Journal of Pharma Sciences and Research, 5(10), 733 (2014). 
RASĀYAN J. Chem.

Vol. 11 | No. 1 |13-17 | January - March | 2018

13. Shreesadh E C, Sandeep Thakur and M.S. Chauhan. Journal of Environmental Science and Sustainability, 1(4), 113 (2013).

14. A.I.Hafez, M.S. El-Manharawy, M.A. Khedr, Desalination, 144 (1-3), 237 (2002).

15. Hanumantha Rao and K. Ravindhranath, Rasayan Journal of Chemistry, 4(2), 1104 (2011).

[RJC-1893/2017] 